\title{
İlkokul Matematik Dersi Öğretim Programı Kazanımlarının TIMSS-2019 Değerlendirme Çerçevesine Göre Analizi ${ }^{a}$
}

\author{
Ahmet DELİL ${ }^{b, c}$, Bülent Nuri ÖZCAN ${ }^{d}$, Okay IŞLAKe
}

Özet

Bu çalışmanın amacı, TIMSS-2019 bilişsel alan becerilerini temel alarak 2018 yılı ilkokul matematik dersi öğretim programındaki kazanımların sınıf düzeylerine ve öğrenme alanlarına göre analizini yapmaktır. Nitel araştırma desenlerinden durum çalışması deseninin uygulandığı çalışmada veri toplama yaklaşımı olarak doküman analizi yapılmış, kazanımların sınıflandırılması amacıyla nitel veri analizi tekniklerinden betimsel analiz kullanılmıştır. Çalışmada, birinci sınıftan dördüncü sınıfa kadar olan toplam 229 tane kazanım ifadesi değerlendirmeye tabi tutulmuş, söz konusu kazanımların bilişsel özelliklerinin 1.'den 4.'ye doğru sınıf düzeylerine göre ve öğrenme alanlarına göre değişimi analiz edilmiştir. Bulgulara göre tüm kazanımların $\% 58$ 'i bilme, \%32'si uygulama ve $\% 10^{\prime}$ u akıl yürütme basamağındadır. Sınıf düzeyleri karşılaştırıldığında, 1 . sınıftan 4. sınıfa doğru gidildikçe bilme düzeyindeki kazanım sayılarının azaldığı, akıl yürütme basamağındaki kazanım sayılarının ise arttığı görülmüştür. Bulgular ışığında sonuçlar tartışılmış ve bazı önerilerde bulunulmuştur.
Anahtar Kelimeler

Matematik Öğretimi

Öğretim Programı

Bilişsel Alanlar

TIMSS

\section{Makale Hakkında}

Geliş Tarihi: 15.11.2019

Kabul Tarihi: 13.03.2020

Doi: $10.18026 /$ cbayarsos.669086

\section{An Analysis of Turkish Primary School Mathematics Curriculum Learning Outcomes in Terms of TIMSS-2019 Assessment Frameworks}

\begin{abstract}
The aim of this study is to analyze learning outcomes of 2018 Turkish primary school mathematics curriculum in terms of their grade level and content domains based on cognitive qualifications of TIMSS-2019 assessment framework. As a qualitative research design this is a case study design that uses document analysis as document collection tool. In order to classify the learning outcomes descriptive analysis is used as a qualitative data analysis technique. Considering their content domains and grade levels, the cognitive requirements of 229 phrases from first to the fourth grades are analyzed. According to the findings, of all learning outcomes about $58 \%$ are in knowing, $32 \%$ are in applying, and $10 \%$ are in reasoning domains. Comparing the grade levels, while the number of learning outcomes of knowing cognitive domain reduces from 1st through 4th, learning outcomes of reasoning cognitive domain raises from 1st through fourth which is affirmative. Results are discussed in the light of findings, and some suggestions are given.
\end{abstract}

Keywords

Mathematics Education

Curriculum

Cognitive Domains

TIMSS

\section{About Article}

Received: 15.11.2019

Accepted: 13.03.2020

Doi: 10.18026/cbayarsos.669086

aBu çalışma kısmen VIII. Uluslararası Eğitimde Araştırmalar Kongresi (ULEAD 2018)'de sunulmuştur.

b İletişim Yazarı: delil@hotmail.com

c Dr. Öğr. Üyesi, Manisa Celal Bayar Üniversitesi/Eğitim Fakültesi, Demirci/Manisa. ORCID: 0000-0003-0234-2816

dDr. Öğr. Üyesi, Manisa Celal Bayar Üniversitesi/Eğitim Fakültesi, Demirci/Manisa. ORCID:0000-0002-7468-7664

${ }^{\text {e }}$ Dr. Öğr. Gör., Akdeniz Üniversitesi, Sağlık Hizmetleri MYO, Antalya. ORCID: 0000-0003-1792-0180 


\section{Giriș}

2017 yılında taslağ 3, 4, 5, 6, 7 ve 8. Sınıflar), bazı değişikliklerle 19/01/2018 tarihinde Milli Ĕ̆itim Bakanlığ1 Talim ve Terbiye Kurulu Başkanlığı tarafından kabul edilmiş ve 2018-2019 eğitim öğretim yılından itibaren ilkokul ve ortaokulların tüm sınıf düzeylerinde uygulanmaya başlanmıştır. Yeni öğretim programında sadece bilgi aktaran bir yapı yerine, bireysel farklılıkları da göz önünde tutan, değer ve beceri kazandırma odaklı, sade bir yapı hedeflendiği ifade edilmektedir. Yeni programın perspektifi de değerler ve yetkinliklerle bütünleşmiş bilgi, beceri ve davranışlara sahip bireyler yetiştirmek olarak belirtilmektedir. Söz konusu değerler adalet, dostluk, dürüstlük, öz denetim, sabır, saygı, sevgi, sorumluluk, vatanseverlik ile yardımseverlik iken; yetkinlikler anadilde iletişim, yabancı dillerde iletişim, matematiksel yetkinlik ve bilim/teknolojide temel yetkinlikler, dijital yetkinlik, öğrenmeyi öğrenme, sosyal ve vatandaşlıkla ilgili yetkinlikler, inisiyatif alma ve girişimcilik ile kültürel farkındalık ve ifade olarak sıralanmaktadır. Yeni programa göre, ilkokul matematik dersinin sayılar ve işlemler, geometri, ölçme ile veri işleme olmak üzere dört öğrenme alanı olup, öğrencilerin yeni matematiksel kavramları önceki kavramların üzerine inşa etmeleri için fırsat verilmesi gerektiğine ilişkin görüş belirtilerek yapılandırmacılık teorisine vurgu yapılmaktadır. Yeni programdaki kazanımlar, öğrenciye kazandırılması planlanan bilgi ve becerilere odaklanır. Söz konusu kazanım sayılarının sinıflara dağ̆lımı 1, 2, 3 ve 4. sinıfta sirasiyla 36, 50, 72 ve 71 olup toplamda 229 tanedir (MEB, 2018).

TIMSS (Trends in International Mathematics and Science Study) ve PISA (Programme for International Student Assessment) gibi uluslararası eğitimi karşılaştırma ve değerlendirme çalışmaları, ülkelerin öğretim programlarında geliştirme veya değişikliğe gitmelerinde etkili olmaktadır (Kadijevich, 2019). Gerçekten, Johansson ve Hansen (2019) de uluslararası katılımlı eğitim araştırmalarından elde edilen bilgilerin karar alma ve eğitim reformlarında önemli olduğunu ifade etmektedirler. TIMSS ilk olarak 1995'te yalnızca 4. sınıf, sonraki her dört yılda bir hem 4 . hem de 8. sınıf öğrencilerinin matematik ve fen bilgisi derslerindeki başarılarını ölçmekte; katılımcı ülkelerin bu derslerdeki yıllara göre başarı eğilimlerini kendi içinde ve birbirleriyle karşılaştırmaktadır. TIMSS bunun yanında, çeşitli anketler aracılığıyla öğrencilerden deneyimleri ile öğretim ve öğrenmeye karşı tutumları hakkında; öğretmen ve okul yöneticilerinden okul ve sınıf kaynakları hakkında, velilerden ise öğrencilerin öğrenme eğilimleri hakkında bilgiler toplamaktadır (Mullis \& Martin, TIMSS 2019 assessment frameworks, 2017).

TIMSS' in 2016 yılı ansiklopedik raporuna göre, katılımcı ülkelerin öğretim programlarındaki reformlar doğrudan veya dolaylı olarak TIMSS sonuçlarından etkilenmiştir. Aynı raporun Türkiye başlı̆̆ında TIMSS'in ülkemizdeki eğitimi takip etmede kullanılan uluslararası göstergelerden biri olduğu (Mullis, Martin, Goh, \& Cotter, 2016); 2012 yılı ansiklopedik raporunun Malezya başlı̆̆ında ise matematik öğretim programlarının TIMSS bilişsel alanlarına göre düzenlendiği ifade edilmektedir (Mullis ve diğerleri, 2012). TIMSS-2019'da sorulan soruların bilişsel alan (cognitive domain) ve öğrenme alanı (content domain) olmak üzere iki boyutu vardır. Tüm soruların bilişsel alanları bilme, uygulama ve akıl yürütme basamaklarından birinde olup, bunların 2019'daki sınavda 4. sınıf hedef yüzdelikleri sırasıyla yüzde 40,40 ve $20^{\prime}$ dir. Öğrenme alanları ise sayılar, ölçme ve geometri ile veri olup, 4 . sinıf hedef yüzdelikleri sırasıyla yüzde 50, 30 ve 20'dir. TIMSS-2019 4. siniflar değerlendirme 
çerçevesindeki soru tipleri yarı yarıya çoktan seçmeli ve açık uçlu şeklindedir (Mullis \& Martin, TIMSS 2019 assessment frameworks, 2017).

Türk öğrenciler TIMSS sinavlarına 4. sinıf düzeyinde sadece 2011 ve 2015 'te katılırken, 8. sinıf düzeyinde 1999, 2007, 2011 ve 2015 yillarında katılmıştır. En son ilan edilen TIMSS-2015 sonuçları bir önceki 2011 sonuçlarına benzer olarak, 4. sınıf Türk öğrencilerinin performanslarının katılımcı ülkelerin ortalaması altında olduğunu göstermektedir. Türk öğrencilerinin TIMSS ve benzeri uluslararası ölçekli sınavlarda gösterdiği görece düşük performansların bir sonucu da 2005, 2013 ve 2017 yıllarındaki öğretim programlarında yapılan reformlardır. Matematik programlarında yapılan bu değişiklikler sonrasında tatmin edici olmasa da TIMSS matematik sinavlarında öğrencilerimiz önceki sinavlara göre ilerleme kaydetmişlerdir (MEB, 2016).

TIMSS katılımcısı bazı ülkelerin matematik öğretim programlarını TIMSS bilişsel alanlarına ve öğrenme alanlarına göre yeniden düzenleyip başarılı oldukları göz önüne alındığında, yeni ilkokul matematik dersi öğretim programımızın TIMSS çerçevesi ile ne kadar uyumlu olduğunu araştırmak anlamlı olacaktır. Nitekim İncikabı, Mercimek, Ayanoğlu, Aliustaoğlu ve Tekin (2016), 2013 yılındaki program değişikliğinden sonra ortaokul matematik dersi öğretim programındaki kazanımların bilişsel düzeylerini TIMSS-2015 çerçevesine göre analiz etmiş; sınıf düzeylerinde ve öğrenme alanlarındaki dağılımları TIMSS hedefleriyle farklılık gösterse de tüm kazanımların \%34'ünün bilme, \%34'ünün uygulama ve \%32'sinin akıl yürütme basamağında olduğu bulgusuna ulaşmışlardır. İlkokul sonrası ilk merkezi sınav özelliği taşıyan İlköğretim ve Ortaöğretim Kurumları Bursluluk Sınavı (İOKBS) 5. sınıf matematik sorularını TIMSS-2019 çerçevesine göre analiz eden Delil (2019) ise yıllara göre soruların bilişsel seviyelerinin dramatik farklılıklar gösterdiğini ifade etmiş ve sınav hazırlayıcılarının bir sınav çerçevesi oluşturarak, bu çerçeveye uygun soru sormalarının isabetli olacağını önermiştir. Diğer bir çalışmada Kılıç, Aslan-Tutak ve Ertaş (2014), ortaokul matematik dersi öğretim programındaki değişiklikleri TIMSS çerçevesine göre incelemiş ve TIMSS'te uygulama düzeyinde maddeler çoğunlukta iken, hem 2009 hem de 2013 öğretim programında bilme düzeyinde kazanımlara daha çok ağırlık verildiği bulgusuna ulaşmışlardır. Aynı çalışmada, bilme düzeyindeki kazanımların fazlalığına rağmen TIMSS2011 çalışmasında öğrencilerimizin en çok sayılar ile geometri öğrenme alanlarında bulunan bilme düzeyindeki sorularda ortalama altında başarı gösterdikleri bilgisi paylaşılmış olup, bu durum oldukça düşündürücüdür. Toptaş, Elkatmış ve Karaca (2012) ise 4. sinıf bir öğrenci çalışma kitabındaki soruları ders öğretim programının öğrenme alanları ile TIMSS-2007 bilişsel alanlarına göre inceledikleri çalışmalarında, alıştırma sorularının TIMSS-2007 yüzdelikleriyle uyumlu olmadığını rapor etmişlerdir. Buna oldukça benzer bir sonuç, 6. sınıf bir matematik ders kitabının alıştırma sorularını TIMSS-2007 bilişsel düzeyleriyle karşılaştıran Coşar ve Delil (2010) tarafından paylaşılmıştır.

TIMSS değerlendirme çerçevesine göre öğretim programı kazanımlarını, ders kitaplarındaki alıştırma sorularını, merkezi sınav sorularını ve öğretmen yapımı testlerdeki matematik sorularını analiz etmek üzere yapılan oldukça fazla sayıda yayın bulunmaktadır. Malezya örneğinde olduğu gibi, ülkelerin matematik öğretim programlarını TIMSS değerlendirme çerçevesine göre hazırladıkları göz önüne alındığında, yeni matematik öğretim programlarındaki kazanımların TIMSS-2019 çerçevesine ne kadar uyduğunu belirlemek anlamlı ve yararlı olacaktır. Bu bağlamda, çalışmanın amacı TIMSS-2019 bilişsel alan becerilerini temel alarak, 2018 yılı ilkokul matematik dersi öğretim programındaki 
kazanımların hem sınıf düzeylerine hem de öğrenme alanlarına göre analizini yapmaktır. Bu amaç doğrultusunda çalışmanın problemi, “2018 ilkokul matematik dersi öğretim programındaki kazanımların TIMSS-2019 bilişsel alanlarına göre dağılımı nasıldır?" şeklinde olup, alt problemler;

(1) İlkokul matematik dersi öğretim programındaki kazanımların TIMSS-2019 bilişsel alanlarına göre dağılımı sınıf düzeyleri açısından nasıldır?

(2) İlkokul matematik dersi öğretim programındaki kazanımların TIMSS-2019 bilişsel alanlarına göre dağılımı öğrenme alanları açısından nasıldır?

şeklindedir.

Bu çabayla, ilköğretim matematik dersi öğretim programımızdaki kazanımlar TIMSS hedef yüzdelikleriyle karşılaştırılabilecek ve her bir öğrenme alanındaki kazanımın bilişsel niteliği belirlenebilecektir. Böylece, öğrencilerimizin katıldıkları uluslararası TIMSS değerlendirme çalışmasında neden istenen başarıyı gösteremediklerine 1 şık tutulabilecektir. Yapılan çalışmalara bakıldığında alan yazında ilkokul matematik dersi öğretim programını TIMSS2019değerlendirme çerçevesindeki bilişsel alanlara göre inceleyen bir çalışmaya rastlanmamıştır. Bu açıdan çalışmanın alan yazına katkı yapabileceği düşünülmektedir.

\section{Yöntem}

$\mathrm{Bu}$ çalışmada araştırmanın amacına uygun olarak nitel araştırma desenlerinden durum çalışması deseni seçilmiştir. Durum çalışması birçok farklı alanda kullanılan, araştırmacının bir durumu, bir programı, olayı, eylemi, süreci ya da bir veya daha fazla bireyi derinlemesine analiz ettiği bir araştırma deseni olarak tanımlanmaktadır (Creswell, Araştırma Deseni (Nitel, Nicel ve Karma Yöntem Yaklaşımları), 2014).

Araştırmada veri toplama yaklaşımı olarak doküman analizi kullanılmıştır. Doküman analizi araştırılması hedeflenen olgu veya olgular hakkında bilgiler içeren yazılı materyallerin analizini kapsamaktadır (Yıldırım \& Şimşek, Sosyal Bilimlerde Nitel Araştırma Yöntemleri, 2016). Bu araştırmanın verilerini, 2018'de Talim Terbiye Kurulunca yayımlanan Matematik Dersi Öğretim Programı (İlkokul ve Ortaokul 1, 2, 3, 4, 5, 6, 7 ve 8. Sinıflar) (MEB, 2018) ve TIMSS-2019 çerçevesi (Mullis \& Martin, TIMSS 2019 Assessment Frameworks, 2017) oluşturmaktadır. Programdaki 229 kazanım; 4 öğrenme alanı, 4 sınıf düzeyi ve 3 bilişsel alan altında sinıflandırılmıştır.

Araştırmada kazanımların sınıflandırılması amacıyla nitel veri analizi tekniklerinden betimsel analiz kullanılmıştır. Betimsel analiz tekniğinde veriler daha önceden belirlenmiş çerçevelere göre değerlendirilip yorumlanır (Yıldırım \& Şimşek, Sosyal Bilimlerde Nitel Araştırma Yöntemleri, 2016). Kazanımları sınıflayabilmek için TIMSS-2019 bilişsel alanlarından yararlanılarak Tablo 1'deki kodlama şeması oluşturulmuştur. Bunun için gerekli izin sağlanmıştır. 
Tablo 1. TIMSS-2019 Çerçevesinden Yararlanılarak Oluşturulmuş Kodlama Şeması (Mullis \& Martin, 2017, s.23-24)

\begin{tabular}{|c|c|}
\hline Bilişsel Alan & Alt Alan ve Açıklaması \\
\hline \multirow{6}{*}{ 1. Bilme } & $\begin{array}{l}\text { 1.1 Hatırlama:Açıklamaları, terminolojiyi, sayı niteliklerini, geometri niteliklerini } \\
\text { ve belirtkeleri hatırlama (örneğin, } a \times b=a b, a+a+a=3 a \text { ). }\end{array}$ \\
\hline & $\begin{array}{l}\text { 1.2 Tanıma:Matematiksel nesneleri tanıma, örneğin şekiller, numaralar, ifadeler ve } \\
\text { miktarlar. Matematiksel denklem olan matematiksel kavramları tanıma. (Örneğin: } \\
\text { Denklemsel kesirler, ondalıklar ve yüzdelikler, basit geometrik figürlerin değişik } \\
\text { oryantasyonları) }\end{array}$ \\
\hline & $\begin{array}{l}\text { 1.3 Sınıflandırma/Sıralama: Nesneleri, şekilleri, sayıları ve ifadeleri ortak } \\
\text { niteliklerine göre sınıflandırma/gruplama; grup üyeleri hakkında doğru kararı } \\
\text { verme ve nesne ve sayıları özelliklerine göre sıralama. }\end{array}$ \\
\hline & $\begin{array}{l}\text { 1.4 Hesaplama: }+,-, \times, \div \text { veya bunların bütün sayılar, ondalıklar, yüzdelikler ve } \\
\text { tamsayılarla olan kombinasyonları için algoritmik prosedürleri yürütme. Tahmini } \\
\text { hesaplamalar için yaklaşı sayıları söyleme, rutin cebirsel yöntemleri yürütme. }\end{array}$ \\
\hline & $\begin{array}{l}\text { 1.5 Çıkarımda Bulunma: Grafiklerden, tablolardan veya diğer kaynaklardan basit } \\
\text { ölçekleri okuma. }\end{array}$ \\
\hline & 1.6 Ölçme: Ölçme araçlarını kullanma, uygun ölçme birimlerini seçme. \\
\hline \multirow{3}{*}{ 2. Uygulama } & $\begin{array}{l}\text { 2.1 Belirleme: Problemlerin çözümü için sıklıkla kullanılan stratejileri, araçları, } \\
\text { etkili ve uygun işlemleri belirleme. }\end{array}$ \\
\hline & $\begin{array}{l}\text { 2.2 Temsil Etme/Modelleme: Veriyi tablo veya grafikte gösterme, problemlerin } \\
\text { çözümü için eşitlik, eşitsizlik, geometrik figür veya diyagram oluşturmak, verilen } \\
\text { matematiksel elemanlar veya ilişkiler için denklemler üretme. }\end{array}$ \\
\hline & $\begin{array}{l}\text { 2.3 Uygulama: Benzer matematiksel kavramlar ve işlemleri içeren problemleri } \\
\text { çözmek için strateji uygulama. }\end{array}$ \\
\hline \multirow{6}{*}{$\begin{array}{l}\text { 3. Akıl } \\
\text { Yürütme }\end{array}$} & $\begin{array}{l}\text { 3.1 Analiz: Matematiksel durumlarda nesneler veya değişkenler arasındaki } \\
\text { ilişkileri kullanma, açıklama veya bunlara karar verme ve bu bilgilerden geçerli } \\
\text { çıkarımlar yapma. }\end{array}$ \\
\hline & $\begin{array}{l}\text { 3.2 Sentez Yapma: Farklı bilgi ve ilgili temsili öğeleri arasında bağlantı kurma ve } \\
\text { ilgili matematiksel fikirler arasında bağlantı kurma. Sonuçları ortaya çıkarma ve } \\
\text { bir sonraki sonuca ulaşabilmek için matematiksel yöntemleri, kavramları ve } \\
\text { gerçekleri birleştirme. }\end{array}$ \\
\hline & $\begin{array}{l}\begin{array}{l}\text { 3.3 Değerlendirme: } \\
\text { değerlendirme. }\end{array} \\
\text { Farklı problem çözme stratejileri ve çözümlerini }\end{array}$ \\
\hline & 3.4 Sonuç Çıkarma: Bilgi ve kanıtın temelinde çıkarımda bulunma. \\
\hline & $\begin{array}{l}\text { 3.5 Genelleme: Sonuçlara daha genel ve daha geniş kabul edilebilir şartlarda } \\
\text { yeniden yer vererek matematiksel düşünme ve problem çözmenin sonucunun } \\
\text { doğru olduğu alanları genişletme. }\end{array}$ \\
\hline & $\begin{array}{l}\text { 3.6 Doğrulama: Matematiksel tartışmaları sağlamak için çözüm ve stratejileri } \\
\text { destekleme. }\end{array}$ \\
\hline
\end{tabular}

Araştırmada kullanılan değerlendirme ölçütleri dikkate alınarak ilkokul matematik dersi öğretim programında yer alan kazanımların bilişsel alanlara nihai sınıflamalarından örnekler Tablo 2'de verilmektedir. 
Tablo 2. Kodlama Örnekleri

\begin{tabular}{llll}
\hline Kazanım no. & Kazanım ifadesi & Bilişsel alan & Alt alan \\
\hline M.1.3.2.1. & Paralarımızı tanır. & Bilme & 1.2 \\
\hline M.2.1.1.4. & $\begin{array}{l}\text { 100'den küçük doğal sayıların basamaklarını } \\
\text { modeller üzerinde adlandırır, basamaklardaki } \\
\text { rakamların basamak değerlerini belirtir. }\end{array}$ & Uygulama & 2.2 \\
\hline M.3.1.4.5. & $\begin{array}{l}\text { 5'e kadar (5 dâhil) çarpım tablosundaki sayıları } \\
\text { kullanarak çarpma işleminde çarpanlardan biri } \\
\text { bir arttırıldığında veya azaltılı̆ı̆ında çarpma } \\
\text { işleminin sonucunun nasıl değiştiğini fark eder. }\end{array}$ & Akıl Yürütme & 3.1 \\
\hline
\end{tabular}

Program kazanımlarını bilişsel alanlara sınıflayabilmek için 2 kodlayıcı bir araya gelerek kodlama şemasını okumuş ve TIMSS'in yayınladığı 4. sınıf sorularının TIMSS tarafından yapılan bilişsel alan sınıflamalarını incelemişlerdir. (Kodlayıcılar bu araştırmayı yürütenlerden ikisidir.) Birlikte bazı kazanım sınıflamaları üzerinde çalıştıktan sonra, birbirlerinden bağımsız olarak bütün kazanımları sınıflamışlardır. Bu sınıflamada değerlendirmeciler arası uyum (inter-rater reliability) 0.81 bulunarak, yeterli sayılabilecek bir güvenirlik bulunmuştur (Neuendorf, 2002). Uyuşma sağlanmayan kazanımlar için bir araya gelinmiş ve uzlaşma sağlanana kadar tartışılmış; böylece nihai sınıflamaya karar verilmiştir.

\section{Bulgular}

Bu bölümde 2018 yılı ilkokul matematik dersi öğretim programındaki kazanımlar sınıf seviyeleri açısından ve öğrenme alanları açısından TIMSS-2019 çerçevesinde belirlenen bilişsel alanlar dikkate alınarak ilişkilendirilmiş ve elde edilen sonuçlar frekanslar ve yüzdeler yardımıyla betimlenmiştir.

\section{Birinci Alt Probleme İlişkin Bulgular}

“illkokul matematik dersi öğretim programındaki kazanımların TIMSS-2019 bilişsel alanlarına göre dağılımı sınıf düzeyi açısından nasıldır?" alt problemine ilişkin bulgular bu bölümde sunulmaktadir.

2018 yılı ilkokul matematik dersi öğretim programında yer alan kazanımların sınıf düzeylerine ve öğrenme alanlarına dağılımı Tablo 3'de verilmektedir. Tabloda hem ilgili öğrenme alanlarının altında yer alan kazanımların sınıf seviyelerine göre dağılımı hem de her sınıf seviyesinde ele alınan toplam kazanım sayısına yer verilmiştir. Söz konusu sayıların toplam kazanım sayısı dikkate alınarak yüzde olarak da gösterilmiştir.

Tablo 3.Öğrenme Alanlarının Sınıf Düzeylerindeki Kazanım Sayıları ve Yüzdeleri

\begin{tabular}{llllll}
\hline \multirow{2}{*}{ Öğrenme Alanı } & \multicolumn{5}{c}{ Sınıf Düzeyi } \\
\cline { 2 - 6 } & 1. sinıf & 2. sinıf & 3. sinıf & 4. sınıf & Toplam \\
\hline
\end{tabular}




\begin{tabular}{lccccc}
\hline & $f(\%)$ & $f(\%)$ & $f(\%)$ & $f(\%)$ & $f(\%)$ \\
\hline Sayılar & $19(17)$ & $25(22)$ & $36(31)$ & $34(30)$ & $114(\% 49.8)$ \\
\hline Geometri & $6(17)$ & $8(22)$ & $10(28)$ & $12(33)$ & $36(\% 15.7)$ \\
\hline Ölçme & $10(14)$ & $16(23)$ & $23(33)$ & $21(30)$ & $70(\% 30.6)$ \\
\hline Veri İşleme & $1(11)$ & $1(11)$ & $3(33)$ & $4(44)$ & $9(\% 3.9)$ \\
\hline Toplam & $36(\% 15.7)$ & $50(\% 21.8)$ & $72(\% 31.4)$ & $71(\% 31.0)$ & $229(\% 100)$ \\
\hline
\end{tabular}

Tablo 3'e göre, en çok kazanımın sayılar öğrenme alanında (\%49.8) yer aldığ1 görülmektedir. Bunu ölçme (\%30.6) ve geometri (\%15.7) takip emektedir. Veri işleme ise 9 kazanımla (\%3.9) en az temsil edilen öğrenme alanıdır. Sınıf düzeyine göre bakıldığında ise en az kazanımın 1. sınıf düzeyinde (\%15.7) olduğu en çok kazanımın ise yaklaşık olarak 4. sınıf seviyesindeki (\%31) ile aynı olmakla birlikte 3. sınıf seviyesinde (\%31.4) olduğu görülmektedir.

Öğrenme alanlarına ilişkin kazanımların sınıf seviyelerine göre dağılımı dikkate alındığında üç durumun dışında çoğunlukla öğrenme alanlarındaki kazanım sayılarının sınıf seviyeleri arttıkça aynı paralelde arttığı görülmektedir. Bunlardan birincisi; sayılar öğrenme alanında 3. sınıf seviyesinde kazanım sayısı 4. sınıf seviyesindekinden 2 fazladır. İkincisi; ölçme öğrenme alanında 3. sınıf seviyesindeki kazanım sayısı dördüncü sınıftakinden 2 fazladır. Üçüncüsü, veri işleme öğrenme alanında 1 . ve 2 . sınıf seviyesinde kazanım sayıları birbirine eşittir.

2018 yılı ilkokul matematik dersi öğretim programında yer alan her bir sınıf düzeyindeki kazanımların TIMSS-2019 bilişsel alanlarına göre sınıflandırması Tablo 4'te sunulmuştur. Tabloda her bir sınıf düzeyindeki kazanımlar, ilgili olduğu bilişsel alan ve alt boyutları ile ilişkilendirilip bilişsel alan ve alt boyutlarının sınıf düzeylerine göre görülme sıklığı ortaya konmuştur. Tablodaki veriler yüzde olarak da gösterilmiştir.

Tablo 4. Her Bir Sınıf Düzeyindeki Kazanımların TIMSS-2019 Bilişsel Alanlarına Göre Dağılımı (\%)

\begin{tabular}{|c|c|c|c|c|c|c|}
\hline \multirow{2}{*}{$\begin{array}{l}\text { BİLİ̧SEL } \\
\text { ALANLAR }\end{array}$} & \multirow{2}{*}{ Alt Boyutlar } & \multicolumn{4}{|c|}{ Sınıf Düzeyi } & \multirow{2}{*}{$\begin{array}{c}\text { GENEL } \\
\text { TOPLAM }\end{array}$} \\
\hline & & 1. sinif & 2. sinif & 3. sinif & 4. sinif & \\
\hline \multirow{7}{*}{ Bilme } & Hatırlama & $2(5.6)$ & $0(0)$ & $1(1.4)$ & $2(2.8)$ & $5(2.2)$ \\
\hline & Tanıma & $3(8.3)$ & $8(16)$ & $11(15.3)$ & $5(7)$ & $27(11.8)$ \\
\hline & Siralama/Sinıflama & $9(25)$ & $5(10)$ & $4(5.6)$ & $5(7)$ & $23(10)$ \\
\hline & Hesaplama & $6(16.7)$ & $10(20)$ & $18(25)$ & $20(28.2)$ & $54(23.6)$ \\
\hline & Çıkarımda Bulunma & $2(5.6)$ & $0(0)$ & $0(0)$ & $1(1.4)$ & $3(1.3)$ \\
\hline & Ölçme & $3(8.3)$ & $5(10)$ & $7(9.7)$ & $5(7)$ & $20(8.7)$ \\
\hline & TOPLAM & $25(69.4)$ & $28(56)$ & $41(56.9)$ & $38(53.5)$ & $132(57.6)$ \\
\hline \multirow{4}{*}{ Uygulama } & Belirleme & $4(11.1)$ & $2(4)$ & $0(0)$ & $2(2.8)$ & $8(3.5)$ \\
\hline & Temsil Etme/Modelleme & $2(5.6)$ & $5(10)$ & $6(8.3)$ & $7(9.9)$ & $20(8.7)$ \\
\hline & Uygulama & $4(11.1)$ & $10(20)$ & $16(22.2)$ & $15(21.1)$ & $45(19.7)$ \\
\hline & TOPLAM & $10(27.8)$ & $17(34)$ & $22(30.6)$ & $24(33.8)$ & $73(31.9)$ \\
\hline \multirow{6}{*}{$\begin{array}{l}\text { Akıl } \\
\text { Yürütme }\end{array}$} & Analiz & $1(2.8)$ & $4(8)$ & $7(9.7)$ & $9(12.7)$ & $21(9.2)$ \\
\hline & Sentez Yapma & $0(0)$ & $1(2)$ & $2(2.8)$ & $0(0)$ & $3(1.3)$ \\
\hline & Değerlendirme & $0(0)$ & $0(0)$ & $0(0)$ & $0(0)$ & $0(0)$ \\
\hline & Sonuç Çıkarma & $0(0)$ & $0(0)$ & $0(0)$ & $0(0)$ & $0(0)$ \\
\hline & Genelleme/Özelleştirme & $0(0)$ & $0(0)$ & $0(0)$ & $0(0)$ & $0(0)$ \\
\hline & Doğrulama & $0(0)$ & $0(0)$ & $0(0)$ & $0(0)$ & $0(0)$ \\
\hline
\end{tabular}




\begin{tabular}{lccccc}
\hline TOPLAM & $1(2.8)$ & $5(10)$ & $9(12.5)$ & $9(12.7)$ & $\mathbf{2 4}(\mathbf{1 0 . 5 )}$ \\
\hline GENEL TOPLAM & $\mathbf{3 6 ( 1 0 0 )}$ & $\mathbf{5 0 ( 1 0 0 )}$ & $\mathbf{7 2 ( 1 0 0 )}$ & $\mathbf{7 1 ( 1 0 0 )}$ & $\mathbf{2 2 9 ( \mathbf { 1 0 0 } )}$ \\
\hline
\end{tabular}

Tablo 4 incelendiğinde, tüm sınıf düzeylerindeki 229 tane kazanımın TIMSS-2019 bilişsel alanlarına göre $\% 57.6$ 'sının bilme, \%31.9'unun uygulama ve $\% 10.5^{\prime}$ inin akıl yürütme alanında olduğu görülmektedir. Alt boyutlar dikkate alındığında ise bilme alanının hesaplama alt boyutunun kazanımların yaklaşık dörtte biri tarafından hedef alındığı anlaşılmaktadır. Buna karşın çıkarımda bulunma (\%1.3) ve sentez yapma (\%1.3) alt boyutlarının ise çok az kazanım ile eşleştiği söylenebilir. İlkokul matematik öğretim programında yer alan tüm kazanımlar dikkate alındığında, akıl yürütme basamağının değerlendirme, sonuç çıkarma, genelleme/özelleştirme ve doğrulama alt boyutlarında hiçbir kazanımın yer almadığı da görülmektedir.

Birinci sınıf düzeyindeki kazanımların TIMSS-2019 bilişsel alanlarına göre dağılımları incelendiğinde kazanımların yaklaşık üçte ikisinin bilme alanında dörtte birinin ise uygulama alanında yer aldığı, buna karşın birinci sınıf seviyesinde sadece bir kazanımın akıl yürütme düzeyinde olduğu anlaşılmaktadır. Kazanımlar alt boyutlara dağılımları açısından değerlendirildiğinde ise genel görünümden farklı olarak en çok kazanımın sıralama/sınıflama (\%25) alt boyutunda yer aldığı, bunu hesaplama (\%16.7) alt boyutunun takip ettiği görülmektedir. Diğer taraftan bilme düzeyinde hatırlama (\%5.6) ve çıkarımda bulunma (\%5.6), uygulama düzeyinde temsil etme/modelleme (\%5.6) ve akıl yürütme düzeyinde analiz (\%2.8) alt boyutları ile ilişkili görece daha az sayıda kazanım olduğu göze çarpmaktadır.

Birinci sınıftakine benzer şekilde ikinci sınıf seviyesinde yer verilen kazanımların çoğunun bilme (\%56) düzeyinde olduğu görülmektedir. Diğer taraftan uygulama ve akıl yürütme düzeyindeki kazanımların ağırlığının birinci sınıfa kıyasla arttığı anlaşılmaktadır. Bu sınıf seviyesindeki kazanımların \%34'ü uygulama, \%10'u ise akıl yürütme düzeyine karşılık gelmektedir. Alt boyutlar açısından dağılım incelendiğinde, bu sınıf seviyesindeki kazanımların bilme düzeyinin hesaplama (\%20) ve uygulama düzeyinin uygulama (\%20) alt boyutlarında diğerlerine göre daha fazla olduğu söylenebilir. Akıl yürütme düzeyinin sentez yapma alt boyutunda ise birinci sınıf seviyesinden farklı olarak bu sınıf seviyesinde bir kazanım yer almaktadır. Bilme düzeyinin hatırlama ve çıkarımda bulunma alt boyutlarına karşılık gelen hiçbir kazanımın olmaması dikkat çeken diğer bir noktadır.

Üçüncü sınıf seviyesinde yer alan kazanımların TIMSS-2019 bilişsel alanlarına göre dağılımları incelendiğinde ikinci sınıf seviyesindeki dağılıma benzer bir dağılım olduğu göze çarpmaktadır. Bu sınıf seviyesindeki 72 kazanımın \%56.9'u bilme, \%30.6'sı uygulama ve \%12.5'i akıl yürütme düzeyindedir. Alt boyutlara bakıldığında, bilme düzeyinde hesaplama alt boyutuyla eşleşen kazanımlar tüm kazanımların dörtte birini oluşturmaktadır. Bunu uygulama düzeyinde uygulama (\%22.2) alt boyutu takip etmektedir. Genelden farklı olarak çıkarımda bulunma ve belirleme alt boyutları ile eşleşen herhangi bir kazanımın bu sınıf seviyesinde yer almadığı söylenebilir. Bilme düzeyinin hatırlama alt boyutunda ise sadece bir kazanıma yer verilmiştir. Akıl yürütme alanında, analiz ve sentez yapma alt boyutlarının dışında ise hiçbir kazanıma yer verilmediği anlaşılmaktadır.

Tablo 3'e göre, dördüncü sınıf seviyesindeki 71 kazanımın \%53.5'i bilme, \%33.8'i uygulama ve \%12.7'si akıl yürütme düzeyindedir. Bu sınıf seviyesindeki kazanımların dağılımının genel olarak üçüncü sınıftakine benzer olduğu söylenebilir. Alt boyutlar dikkate alındığında da 
üçüncü sınıftakine benzer olarak en çok kazanımın hesaplama (\%28.2) ve uygulama (\%21.1) alt boyutları ile ilişkilendirildiği görülmektedir. Hatırlama (\%2.8), çıarımda bulunma (\%1.4) ve belirleme (\%2.8) alt boyutları ile ilişkilendirilmiş kazanımların sayısı diğerlerine göre daha azken sentez yapma, değerlendirme, sonuç çıkarma, genelleştirme/özelleştirme ve doğrulama alt boyutlarında biç bir kazanıma yer verilmemiştir.

TIMSS-2019 bilişsel alanları ile ilişkilendirilen kazanımların sınıf sevilerine göre dă̆ılımı yüzde olarak Şekil 1'de verilmektedir. Şekil incelendiğinde birinci sınıftaki kazanımların bilişsel düzeylerinin dağılımlarının diğer sınıflardakinden daha farklı olduğu göze çarpmaktadır. Son üç sınıf düzeyindeki kazanımların bilişsel seviyelerinin birbirlerine oldukça yakın oranlarda olduğu söylenebilir. Bilme düzeyinde yer alan kazanımların yoğunlukla birinci sınıf seviyesinde (\%69) olduğu, diğer sınıf seviyelerinde ise tüm kazanımların yaklaşık yarısını oluşturduğu görülmektedir. Uygulama düzeyinde olan kazanımların oranı tüm sınıf seviyelerinde birbirlerinden önemli ölçüde farklılaşmamakla birlikte en az birinci sınıf seviyesinde (\%28) temsil edilmektedir. Tüm düzeyler içerisinde en az kazanımın karşılık geldiği akıl yürütme düzeyine karşılık gelen kazanımların oranının sınıf seviyesi yükseldikçe arttığı anlaşılmaktadır. Bu oran birinci sınıf seviyesinde \%3 olarak gerçekleşirken ikinci sınıfta \%10, üçüncü sınıfta \%12 ve son sınıfta \%13 olarak ortaya çıkmıştır.

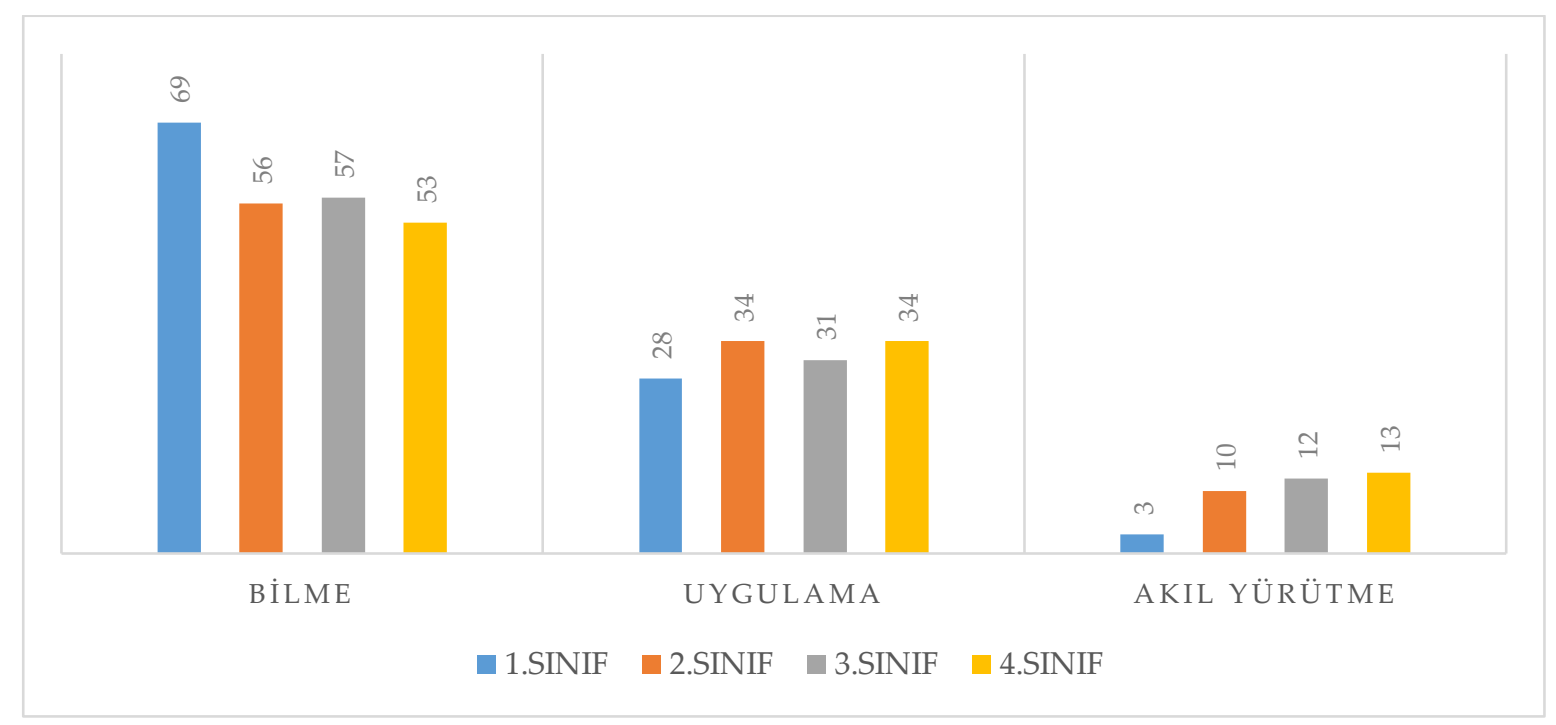

Şekil 1. TIMSS-2019 Bilişsel Alanları ile İlişkilendirilen Kazanımların Sınıf Sevilerine Göre Dağılımı (\%)

İkinci Alt Probleme İlişkin Bulgular

“ilkokul matematik dersi öğretim programındaki kazanımların TIMSS-2019 bilişsel alanlarına göre dağılımı öğrenme alanları açısından nasıldır?" alt problemine ilişkin bulgular bu alt bölümde sunulmaktadır.

Tablo 5. Her Bir Öğrenme Alanındaki Kazanımların TIMSS-2019 Bilişsel Alanlarına Göre Dağılımı (\%)

\begin{tabular}{llccc}
\hline \multirow{2}{*}{ BİLIŞSEL } & Alt Boyutlar & \multicolumn{3}{c}{ ÖĞRENME ALANI } \\
\cline { 3 - 5 } ALANLAR & $\begin{array}{c}\text { Sayılar ve } \\
\text { Isslemler }\end{array}$ & Geometri & Ölçme & $\begin{array}{c}\text { Veri } \\
\text { İşleme }\end{array}$ \\
\hline
\end{tabular}




\begin{tabular}{|c|c|c|c|c|c|}
\hline \multirow{7}{*}{ Bilme } & Hatırlama & $2(1.8)$ & $2(5.6)$ & $1(1.4)$ & $0(0)$ \\
\hline & Tanıma & $7(6.1)$ & $10(27.8)$ & $10(14.3)$ & $0(0)$ \\
\hline & Siralama/Sınıflama & $11(9.6)$ & $6(16.7)$ & $6(8.6)$ & $0(0)$ \\
\hline & Hesaplama & $49(43)$ & $0(0)$ & $5(7.1)$ & $0(0)$ \\
\hline & Çıkarımda Bulunma & $0(0)$ & $0(0)$ & $1(1.4)$ & $2(22.2)$ \\
\hline & Ölçme & $0(0)$ & $2(5.6)$ & $18(25.7)$ & $0(0)$ \\
\hline & Toplam & $69(60.5)$ & $20(55.6)$ & $41(58.6)$ & $2(22.2)$ \\
\hline \multirow{4}{*}{ Uygulama } & Belirleme & $7(6.1)$ & $0(0)$ & $1(1.4)$ & $0(0)$ \\
\hline & Temsil Etme/Modelleme & $8(7)$ & $8(22.2)$ & $2(2.9)$ & $2(22.2)$ \\
\hline & Uygulama & $21(18.4)$ & $5(13.9)$ & $17(24.3)$ & $2(22.2)$ \\
\hline & Toplam & 36 (31.6) & $13(36.1)$ & $20(28.6)$ & $4(44.4)$ \\
\hline \multirow{8}{*}{ Akıl Yürütme } & Analiz & $9(7.9)$ & $3(8.3)$ & $9(12.9)$ & $0(0)$ \\
\hline & Sentez Yapma & $0(0)$ & $0(0)$ & $0(0)$ & $3(33.3)$ \\
\hline & Değerlendirme & $0(0)$ & $0(0)$ & $0(0)$ & $0(0)$ \\
\hline & Sonuç Çıkarma & $0(0)$ & $0(0)$ & $0(0)$ & $0(0)$ \\
\hline & Genelleme/Özelleştirme & $0(0)$ & $0(0)$ & $0(0)$ & $0(0)$ \\
\hline & Doğrulama & $0(0)$ & $0(0)$ & $0(0)$ & $0(0)$ \\
\hline & Toplam & $9(7.9)$ & $3(8.3)$ & $9(12.9)$ & $3(33.3)$ \\
\hline & GENEL TOPLAM & $114(49.8)$ & $36(15.7)$ & $70(30.6)$ & $9(3.9)$ \\
\hline
\end{tabular}

2018 yılı ilkokul matematik dersi öğretim programında yer alan her bir öğrenme alanındaki kazanımların TIMSS 2019 bilişsel alanlarına göre dağılımı Tablo 5'te verilmektedir. Tabloda her bir öğrenme alanındaki kazanımlar, ilgili olduğu bilişsel alan ve alt boyutları ile ilişkilendirilerek kazanımların öğrenme alanlarına göre görülme sıklığı ortaya konulmuştur. Tablodaki veriler yüzde olarak da gösterilmiştir.

Her bir öğrenme alanındaki kazanımların bilişsel düzeylerine bakıldığında sayılar öğrenme alanındaki 114 kazanımın \%60.5'inin bilme, \%31.6'sının uygulama ve \%7.9'unun da akıl yürütme düzeyinde olduğu görülmektedir. Alt boyutlara bakıldığında ise sayılar öğrenme alanındaki kazanımların yarıya yakınının bilme bilişsel alanının hesaplama alt boyutu ile ilişkilendirildiği anlaşılmaktadır. Uygulama bilişsel alanında uygulama alt boyutunun ve akıl yürütme bilişsel alanında da analiz alt boyutunun ön plana çıktığı söylenebilir. Genel durumdan farklı olarak çıkarımda bulunma, ölçme ve sentez yapma alt boyutları ile eşleştirilebilen hiçbir kazanım yoktur.

Geometri öğrenme alanında bulunan kazanımların bilişsel düzeylerinin dağılımı sayılar öğrenme alanındakine benzer bir nitelik taşımaktadır. Tablo 5'e göre, geometri öğrenme alanındaki 36 kazanımın \%55.6'sı bilme, \%36.1'i uygulama ve \%8.3'ü akıl yürütme düzeyindedir. Alt boyutlar açısından bazı farklılıklar göze çarpmaktadır. Sayılar öğrenme alanına göre daha homojen bir yapıda olan bu dağılıma göre bilme bilişsel alanında tanıma (\%27.8), uygulama bilişsel alanında temsil etme/modelleme (\%22.2) ve akıl yürütme bilişsel alanında da analiz (\%8.3) alt boyutları ön plana çıkmaktadır. Bilme bilişsel alanında hesaplama ve çıkarımda bulunma alt boyutları, uygulama bilişsel alanının belirleme alt boyutu ve akıl yürütme bilişsel alanının sentez yapma alt boyutunda kazanıma rastlanmamıştır.

Tablo 5 incelendiğinde ölçme öğrenme alanındaki 70 kazanımın \%58.6'sının bilme, \%28.6'sının uygulama ve \%12.9'unun ise akıl yürütme bilişsel alanı ile eşleştirildiği görülmektedir. Ölçme öğrenme alnında yer alan kazanımların alt boyutlara göre dağılımına bakıldığında bilme ve 
uygulama bilişsel alanlarında yer alan alt boyutlardan her biri ile en az bir kazanımın eşleştirildiği görülmektedir. Akıl yürütmede ise analiz alt boyutunun dışında kazanım atanabilen bir alt boyut bulunmamaktadır. Bilme bilişsel alanında ölçme (\%25.7), uygulama bilişsel alanında uygulama (\%24.3) ise en çok kazanım eşleştirilen alt boyutlar olarak ön plana çıkmaktadır.

Tablo 5'e göre veri işleme öğrenme alanındaki kazanımların dağılımının diğer öğrenme alanlarına göre farklılıklar gösterdiği söylenebilir. Diğer öğrenme alanlarında en çok eşleştirilen bilişsel alan bilme iken veri işleme bilişsel alanında \%44.4 ile uygulamadır. Bunu \%33.3'ü akıl yürütme takip etmekte ve bilme bilişsel alanı ile kazanımların ancak \%22.2'sinin eşleştirildiği anlaşılmaktadır. Veri işleme öğrenme alanında yer alan kazanımların alt boyutlardan sadece dördü ile eşleştirildiği görülmektedir. Bunlar \%33.3 ile sentez yapma, $\% 22.2$ ile çıkarımda bulunma, \%22.2 ile temsil etme/modelleme ve \%22.2 ile uygulamadır.

Her bir öğrenme alanındaki kazanımların TIMSS-2019 bilişsel alanlarına göre değişimleri Şekil 2'te verilmektedir. Şekil incelendiğinde genel olarak sayılar, geometri ve ölçme öğrenme alanlarında yer alan kazanımların TIMSS-2019 bilişsel alanlarına dağılımının benzer olduğu, buna karşın veri işleme öğrenme alanında farklılaşma olduğu söylenebilir. Bilme bilişsel alanı ile eşleştirilen kazanımların, sayılar (\%60), geometri (\%56) ve ölçme (\%58) öğrenme alanlarında birbirine yakın oranda ve en büyük yüzdeye sahip olduğu buna karşılık veri işleme öğrenme alanında kazanımların yaklaşık dörtte birine karşılık geldiği görülmektedir. Uygulama bilişsel alanı ile ilişkilendirilen kazanımlar analiz edildiğinde ise veri işleme öğrenme alanı dışındaki üç öğrenme alanında da birbirine yakın oranlara ve yaklaşık tüm kazanımların üçte birine karşılık gelecek şekilde bir sonuç ortaya çıktığı anlaşılmaktadır. Bu oran veri işleme öğrenme alanında \%45'tir. Akıl yürütme bilişsel alanındaki en yüksek oranın ise veri işleme (\%33) öğrenme alanında olduğu, bunu \%13 ile ölçme ve \%8 ile sayılar ve geometri öğrenme alanlarının takip ettiği görülmektedir.

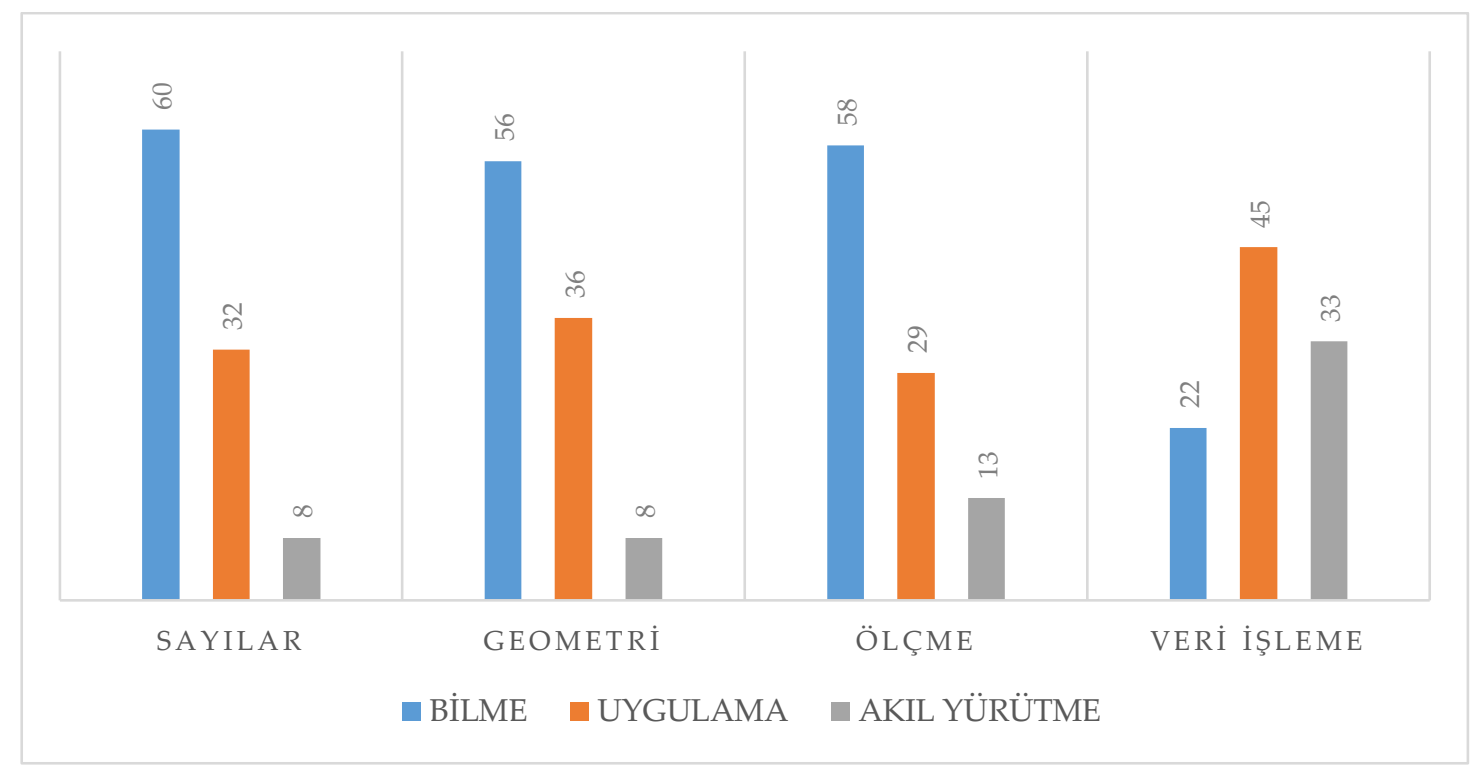

Şekil 2. Her Bir Öğrenme Alanındaki Kazanımların TIMSS-2019 Bilişsel Alanlarına Göre Değişimi 


\section{Tartışma, Sonuç ve Öneriler}

Bütün sınıf düzeylerindeki 229 tane kazanımın \%58'i bilme, \%32'si uygulama ve \%10'u akıl yürütme basamağında olduğundan, en fazla bilme ve en az akıl yürütme basamağında kazanım olduğu anlaşılmaktadır. İlkokula yeni adım atmış bir öğrenci için bilme basamağında bulunan soru sayısının daha yüksek olması olumlu bir durumdur. Ancak TIMSS, 4. sinıftaki bütün soruların bilişsel düzey hedef yüzdeliklerini bilme, uygulama ve akıl yürütme için sırasıyla \%40, \%40 ve \%20 olarak vermektedir. 4. sınıf programımızdaki kazanımların \%53'ü bilme, \%34'ü uygulama ve \%13'ü akıl yürütme düzeyinde olup TIMSS ile karşılaştırıldığında görece daha düşük bilişsel seviyede oldukları görülmektedir. Delil'e (2019) göre 4. sınıf sonrasında yapılan ilk sınav olma özelliğini taşıyan 5. sınıflar İOKBS matematik sınavında sorulan soruların \%26'sı bilme, \%38'i uygulama ve \%36's1 akıl yürütme seviyesindedir. Görülüyor ki sorulan soruların toplamda \%74'ü üst düzey bilişsel beceri gerektirirken, yeni işlenmiş olan 4. sınıf kazanımlarının toplamda yalnızca \%47'si üst düzey bilişsel beceri gerektirmektedir. Bu durum, TIMSS gibi uluslararası ölçekteki sınavlarda aldığımız başarısız sonuçların bir nedeni olabilir. Buna göre, üst düzey bilişsel beceri gerektiren kazanım sayısının son sınıflara doğru arttırılması önerilmektedir.

Şekil 1'de görüldüğ̈ü gibi, sınıf düzeyi 1. sınıftan 4. sınıfa doğru arttıkça kazanımların bilişsel seviyeleri benzer olmakla beraber artış göstermektedir. Örneğin, bilme, uygulama ve akıl yürütme yüzdeleri sirasıyla 1. sinıfta 69,28 ve 3 iken; 2 . sinıfta bu yüzdeler 56, 34, 10; 3. sınıfta 57, 31, 12 ve 4. sınıfta 53, 34, 13 ‘tür. Bu sonuç 2013 ortaokul matematik öğretim programı kazanımlarını analiz eden İncikabı ve diğerlerinin (2016) sonuçları ile benzerlik göstermemektedir: Ortaokuldaki kazanımların sınıf bazında bilişsel düzeylerinin yüzdeleri 5. sinıfta 42, 35 ve 23 iken; 6. sinıfta bu yüzdeler 30, 29, 41; 7. sinıfta 35, 40, 25 ve 8. sınıfta 30, 35, 35 'tir.Ortaokul matematik öğretim programı kazanımlarının bilişsel seviyeleriyle karşılaştırıldığında ilkokulda göreli olarak düşük bilişsel seviye kazanım dağılımı olması olumlu bir durum olarak görülebilir. Ancak, ilkokul matematik öğretim programı kazanımları kendi içinde değerlendirildiğinde, tüm kazanımlar içinde akıl yürütme bilişsel alanındaki kazanımların yüzdesinin artırılması uygun olacaktır.

Bulgulara göre, sayılar ve işlemlerdeki 114 kazanımın \%60' 1 bilme, \%32'si uygulama ve \%8'i akıl yürütme; geometrideki 36 kazanımın \%56'sı bilme, \%36's1 uygulama ve \%8'i akıl yürütme; ölçmedeki 70 kazanımın \%59'u bilme, \%29'u uygulama ve \%13'ü akıl yürütme; veri işlemedeki 9 kazanımın \%22'si bilme, \%45'i uygulama ve \%33'ü akıl yürütme basamağındadır. Buna göre, az sayıdaki veri işleme hariç, diğer öğrenme alanlarındaki kazanımların bilişsel seviyelerinin dağılımının oldukça benzer olduğu, bilişsel seviye yükseldikçe kazanım sayısının azaldığı görülmektedir. Bu durum, gelişimin basitten karmaşığa ilerlemesi ilkesiyle uyuşmaktadır. Bu sonuç, İncikabı ve diğerleri (2016)'nın ortaokul sayılar ve işlemler öğrenme alanındaki kazanımların dağılımı için buldukları sonuçlara benzememektedir: Onların bulgularına göre, bu öğrenme alanındaki kazanımların \%38'i bilme, \%28'i uygulama ve \%34'ü akıl yürütme basamağındadır. Ortaokul programı ile karşılaştırıldığında ilkokul programında daha çok bilme öğrenme alanında kazanıma yer verilmesi doğaldır. Özellikle sayılar ve işlemler ile geometri öğrenme alanlarındaki kazanımlardan, akıl yürütme basamağında olanların sayısının daha çok olması TIMSS hedef yüzdeliklerine yaklaşmak açısından önemli görülmektedir. Bu nedenle, bu öğrenme alanlarındaki kazanımların bilişsel seviyelerinin arttırılması önerilmektedir. 


\section{Kaynakça}

Coşar, N., \& Delil, A. (2010). 6. sınıf matematik ders kitabındaki alıştırmaların TIMSS-2007 bilişsel alanlarına göre analizi. International Conference on New Horizons in Education, Famagusta, June 23-25 2010 (s. 17-21). Famagusta: INTE.

Creswell, J. W. (2014). Araştırma deseni (nitel, nicel ve karma yöntem yaklaşımları). (S. B. Demir, Çev.) Ankara: Eğiten Kitap.

Delil, A. (2019). How fifth graders are assessed through central exams in Turkey: a comparison with TIMSS 2019 assessment framework. International Online Journal of Educational Sciences, 11(3), 222-234.

İncikabı, L., Mercimek, O., Ayanoğlu, P., Aliustaoğlu, F., \& Tekin, N. (2016). Ortaokul matematik dersi öğretim programı kazanımlarının TIMSS bilişsel alanlarına göre değerlendirilmesi. İlköğretim Online, 15(4), 1149-1163.

Johansson, S., \& Hansen, K. (2019). Are mathematics curricula harmonizing globally over time? Evidence from TIMSS national research coordinator data. EURASIA Journal of Mathematics, Science and Technology Education, 15(2), 1-11.

Kadijevich, D. M. (2019). Influence of TIMSS research on the mathematics currıculum in Serbia: educational standards in primary education. The Teaching of Mathematics, XXII(1), 33-41.

Kılıç, H., Aslan-Tutak, F., \& Ertaş, G. (2014). TIMSS merceğiyle ortaokul matematik öğretim programındaki değişiklikler. Mersin Üniversitesi Eğitim Fakültesi Dergisi, 10(2), 129-141.

MEB. (2016). TIMSS 2015 ulusal matematik ve fen bilimleri ön raporu 4. ve 8. siniflar. Ankara: Milli Eğitim Bakanlığı.

MEB. (2018). Matematik dersi öğretim programı (ilkokul ve ortaokul 1, 2, 3, 4, 5, 6, 7 ve 8. siniflar). Ankara.

Mullis, I. V., \& Martin, M. O. (2017). TIMSS 2019 assessment frameworks. TIMSS and PIRLS International Study Center. Chestnut Hill, MA: Lynch School of Education, Boston College.

Mullis, I. V., Martin, M., Minnich, C., Stanco, G., Arora, A., Centurino, V., \& Castle, C. (2012). TIMSS 2011 encyclopedia: education policy and curriculum in mathematics and science, Volumes 1 and 2. TIMSS \& PIRLS International Study Center. Chestnut Hill, MA: Boston College.

Mullis, I., Martin, M., Goh, S., \& Cotter, K. (2016). TIMSS 2015 encyclopedia: education policy and curriculum in mathematics and science. TIMSS \& PIRLS International Study Center. Chestnut Hill, MA: Boston College.

Neuendorf, K. A. (2002). The content analysis guidebook. Chicago: Sage Publications.

Toptaş, V., Elkatmış, M., \& Karaca, E. T. (2012). İlköğretim 4. sınıf matematik programının öğrenme alanları ile matematik öğrenci çalışma kitabındaki soruların zihinsel alanlarının TIMSS'e göre incelenmesi. Ahi Evran Üniversitesi Kırşehir Eğitim Fakültesi Dergisi (KEFAD), 13(1), 17-29.

Yıldırım, A., \& Şimşek, H. (2016). Sosyal bilimlerde nitel araştırma yöntemleri (10 b.). Ankara: Seçkin. 